\title{
Comment on "Plasmatic adipocyte biomarkers and foot pain associated with flatfoot in schoolchildren with obesity"
}

1. Professor of biochemistry and molecular biology, Rehabilitation Research Chair, College of Applied Medical Sciences, King Saud University, Riyadh, KSA. 2. Department of Anatomy, Faculty of Medicine, Mansoura University, Egypt.

Obesity presents a major impact on the quality of lifestyle and essential physical activities such as walking ability, aerobic capacity, and muscle strength'. In younger individuals, as well as in adults, obesity has been associated with a range of bone and musculoskeletal disorders, particularly the development and progression of knee osteoarthritis (OA) and foot deformations ${ }^{1-3}$. Maximum loads on the knee and hip joints can create considerable variation in peak loads and significant effects on the function and structure of the foot ${ }^{4-6}$. It has been reported that obesity in children negatively impacts foot structure and function; the feet are broader, flatter, rounder, and may have a deformity in ligamentous laxity within the foot that exerts a position of extreme pronation, known as flat foot, which is extended even in adolescent or adult feet ${ }^{6-9}$. In addition, the abnormality in foot structure, such as flat foot, makes the foot supple (or prone to collapse) and lacks the ability to supinate in order to form a rigid lever during push-off in gait ${ }^{10-12}$. In young obese children and adolescents, photography, computed tomography scans, and other anthropometric measurements have shown that excessive increase in weight-bearing forces may cause micro-trauma to the ligaments and muscular structures, damaging soft tissue and increasing the risk of joint collapse and flat feet ${ }^{9-15}$.

Finally, supporting comments on plasmatic adipocyte biomarkers and foot pain associated with flatfoot in schoolchildren with obesity ${ }^{12}$, many research works have reported that adipocytokines, particularly adiponectin, leptin, and resistin, have a significant association as physiological biomarkers of childhood obesity, with foot pain and flat foot among young and older ages with obesity ${ }^{16-20}$. These markers along with pro-inflammatory ones (TNF- $\alpha$, IL-6) showed a significant association with bone mineral density (BMD) and bone mineral content (BMC) ${ }^{20-23}$. Thus, early identification of any structural abnormalities in the biomechanics of bone and its related biomarkers including adipocytokines is required to minimize the risk of future functional complications across a lifespan, particularly in childhood obesity. In addition, controlled exercise training programs of moderate-intensity are advised to minimize the potential risks of childhood obesity on the musculoskeletal system ${ }^{19-23}$. 
PAlaVRas-Chave: Biomarcadores. Adipócitos. Pé chato. Obesidade. Criança. Dor/etiologia.

\section{REFERENCES}

1. Lyytinen T, Liikavainio T, Pääkkönen M, Gylling H, Arokoski JP. Physical function and properties of quadriceps femoris muscle after bariatric surgery and subsequent weight loss. J Musculoskelet Neuronal Interact. 2013;13(3):329-8.

2. Arokoski IP, Eskelinen A, Helminen E-E, Kettunen I, Malmivaara A, Mattila $V$, et al. Treatment of knee and hip osteoarthritis (online). Current Care guideline. Working group set up by the Finnish Medical Society Duodecim and the Finnish Orthopaedic Society. Helsinki: Finnish Medical Society Duodecim; 2012. Available from: http://www.kaypahoito.fi

3. Perttunen J. Foot loading in normal and pathological walking [Dissertation] Jyväskylä: University of Jyväskylä; 2002.

4. Simonsen EB, Dyhre-Poulsen P, Voigt M, Aagaard P, Siøgaard G, BojsenMøller F. Bone-on-bone forces during loaded and unloaded walking. Acta Anat (Basel). 1995;152(2):133-42.

5. Segal NA, Yack HJ, Khole P. Weight, rather than obesity distribution, explains peak external knee adduction moment during level gait. Am J Phys Med Rehabil. 2009;88(3):180-8.

6. Vartiainen P, Bragge T, Lyytinen T, Hakkarainen M, Karjalainen PA, Arokoski P. Kinematic and kinetic changes in obese gait in bariatric surgery-induced weight loss. J Biomech. 2012;45(10):1769-74.

7. Chen KC, Yeh C), Tung LC, Yang JF, Yang SF, Wang CH. Relevant factors influencing flatfoot in preschool-aged children. Eur J Pediatr. 2011;170(7):931-6.

8. Niederer I, Kriemler S, Zahner L, Bürgi F, Ebenegger V, Marques P, et al. $\mathrm{BMI}$ group-related differences in physical fitness and physical activity in preschool-age children: a cross-sectional analysis. Res Q Exerc Sport. 2012;83(1):12-9.

9. Roberts D, Veneri D, Decker R, Gannotti M. Weight status and gross motor skill in kindergarten children. Pediatr Phys Ther. 2012;24(4):353-60.

10. Kessler J, Koebnick C, Smith N, Adams A. Childhood obesity is associated with increased risk of most lower extremity fractures. Clin Orthop Relat Res. 2013;471(4):1199-207.

11. Yan SH, Zhang K, Tan GQ, Yang J, Liu ZC. Effects of obesity on dynamic plantar pressure distribution in Chinese prepubescent children during walking. Gait Posture. 2013;37(1):37-42.
12. Alghadir AH, Gabr SA, Rizk AA. Plasmatic adipocyte biomarkers and foot pain associated with flatfoot in schoolchildren with obesity. Rev Assoc Med Bras. 2019;65(8):1061-6.

13. Dufour AB, Losina E, Menz HB, LaValley MP, Hannan MT. Obesity, foot pain and foot disorders in older men and women. Obes Res Clin Pract. 2017;11(4):445-53.

14. Mickle KJ, Steele JR. Obese older adults suffer foot pain and foot-related functional limitation. Gait Posture. 2015;42(4):442-7.

15. Tanamas SK, Wluka AE, Berry P, Menz HB, Strauss B|, Davies-Tuck M et al. Relationship between obesity and foot pain and its association with fat mass, fat distribution, and muscle mass. Arthritis Care Res (Hoboken). 2012;64(2):262-8.

16. Butterworth PA, Urquhart DM, Landorf KB, Wluka AE, Cicuttini FM, Menz $\mathrm{HB}$. Foot posture, range of motion and plantar pressure characteristics in obese and non-obese individuals. Gait Posture. 2015;41(2):465-9.

17. Gruodyte R, Jürimäe J, Cicchella $A$, Stefanelli $C$, Passariello $C$, Jürimäe $T$. Adipocytokines and bone mineral density in adolescent female athletes. Acta Paediatr. 2010;99(12):1879-84

18. Haider DG, Holzer G, Schaller G, Weighuber D, Widhalm K, Wagner O, et al. The adipokine visfatin is markedly elevated in obese children. J Pediatr Gastroenterol Nutr. 2006;43(4):548-9.

19. Pourghasem M, Kamali N, Farsi M, Soltanpour N. Prevalence of flatfoot among school students and its relationship with BMI. Acta Orthop Traumatol Turc. 2016;50(5):554-7.

20. Cetin A, Sevil S, Karaoglu L, Yucekaya B. Prevalence of flat foot among elementary school students, in rural and urban areas and at suburbs in Anatolia. Eur J Orthop Surg Traumatol. 2011;21:327-31.

21. Okely AD, Trost SG, Steele JR, Cliff DP, Mickle K. Adherence to physica activity and electronic media guidelines in Australian pre-school children J Paediatr Child Health. 2009;45(1-2):5-8.

22. Chen KC, Tung LC, Yeh C|, Yang IF, Kuo IF, Wang CH. Change in flatfoot of preschool-aged children: a 1-year follow-up study. Eur J Pediatr. 2013;172(2):255-60

23. Mickle KJ, Cliff DP, Munro BJ, Okely AD, Steele JR. Relationship between plantar pressures, physical activity and sedentariness among preschoo children. J Sci Med Sport. 2011;14(1):36-41. 